\title{
Localized Hepatic Tuberculosis in a 14-Year Old Bangladeshi Girl: A Case Report
}

\author{
Md Rafiqul Islam¹, Md Nazmul Hassan ${ }^{1}$, Urmy Roy ${ }^{1}$, Md Benzamin*1, Aysha Sabiha ${ }^{1}$ and Md \\ Rukunuzzaman ${ }^{2}$ \\ ${ }^{1}$ Department of Pediatric Gastroenterology and Nutrition, Bangabandhu Sheikh Mujib Medical University (BSMMU), Bangladesh
}

${ }^{2}$ Professor, Department of Pediatric Gastroenterology and Nutrition, Bangabandhu Sheikh Mujib Medical University (BSMMU), Dhaka, Bangladesh

*Corresponding author: Md Benzamin, Department of Pediatric Gastroenterology and Nutrition, Bangabandhu Sheikh Mujib Medical University (BSMMU), Dhaka, Bangladesh

\begin{tabular}{|c|c|}
\hline ARTICLE INFO & ABSTRACT \\
\hline Received: 室 July 08, 2020 & \multirow{3}{*}{$\begin{array}{l}\text { Tuberculosis is one of the most common diseases in Bangladesh. It can present } \\
\text { with variable clinical manifestations. Isolated Hepatic tuberculosis is not a common } \\
\text { disease; the presentation of hepatic tuberculosis maybe without having a history of } \\
\text { any active pulmonary TB or military TB. Patients usually present without having any } \\
\text { typical symptoms; so, it is difficult for a physician to diagnose the disease quickly. The } \\
\text { patient presenting with the space-occupying lesion in the liver is confused with abscess, } \\
\text { hepatoma, or metastases. As the treatment modality of localized hepatic tuberculosis } \\
\text { is anti-tubercular drugs, the prognosis is very good in comparison to other differential } \\
\text { diagnoses. Here we are presenting a case of isolated hepatic tuberculosis. }\end{array}$} \\
\hline Published: 慧 July 23, 2020 & \\
\hline $\begin{array}{l}\text { tation: Md Rafiqul Islam, Nazmul Has- } \\
\text { n, Urmy Roy, Md Benzamin, Aysha Sabi- } \\
\text {, Md Rukunuzzaman. Localized Hepatic } \\
\text { berculosis in a 14-Year Old Bangladeshi } \\
\text { rl: A Case Report. Biomed J Sci \& Tech Res }\end{array}$ & \\
\hline 9(1)-2020. BJSTR. MS.ID.004748. & $\begin{array}{l}\text { Abbreviation: TB: Tuberculosis; CLD: Chronic Liver Disease; Hb: Hemoglobin; } \\
\text { ESR: Erythrocyte Sedimentation Rate; PT: Prothrombin Time; INR: International }\end{array}$ \\
\hline $\begin{array}{l}\text { eywords: Tuberculosis; Liver } \\
\text { pace occupying lesion of the liver }\end{array}$ & $\begin{array}{l}\text { Normalization Ration; LDH: Lactate Dehydrogenase; MT: Mantoux Test; CT: Computed } \\
\text { Tomography; USG: Ultrasonogram; FNAC: Fine needle aspiration cytology }\end{array}$ \\
\hline
\end{tabular}

\section{Introduction}

Tuberculosis (TB) is a common infection in different countries of Asia and Africa. Liver involvement can occur in both pulmonary and extra-pulmonary tuberculosis but clinically it may be silent [1]. Hepatic involvement has been described in $90 \%$ of miliary TB, $75 \%$ of extra-hepatic TB, and $25 \%$ of pulmonary TB [2]. Presenting symptoms in these settings are mainly those of military tuberculosis [2]. A South African study showed that hepatic tuberculosis considered for $1.2 \%$ of all cases of tuberculosis diagnosed at a general hospital [3]. In Bangladesh, there are few cases of hepatic tuberculosis reported to date. Tuberculosis (TB) in the liver can be classified into three types: a. Secondary to miliary TB (commonest form accounts 50-80\% cases); b. Granulomatous disease (tuberculous hepatitis) due to TB; and c. Localized hepatic TB with or without bile duct involvement $[4,5]$. Isolated hepatobiliary TB is still unusual and accounts for $<1 \%$ of all diagnosed TB $[4,6]$. In localized hepatic TB with bile, duct involvement presents with obstructive jaundice and without bile, duct involvement presents with solitary or multiple nodular mass lesions in liver parenchyma [5]. The rarest type of tuberculous lesion in the liver is isolated hepatic tuberculoma and it often resembles a neoplastic liver disease (primary or solitary metastatic nodule) [7]. Anti-tubercular therapy is the treatment of choice in isolated hepatic tuberculoma whereas other neoplastic lesions need surgical or chemotherapeutic intervention. Imaging modalities need to identify the lesion but it cannot differentiate the hepatic tuberculoma from other neoplastic mimickers. Biopsy and histopathology need to diagnose it correctly. Here we reported a rare case of isolated hepatic tuberculoma of a 14 year female patient presenting as a solitary nodular lesion.

\section{Case report}

A 14-year-old female patient came with nausea, jaundice, and right hypochondriac pain for 20 days. S For the last 2 months she had also suffering from fever and weight loss. Fever was low grade, intermittent, and especially occurs in the evening. Weight loss was 3 
$\mathrm{kg}$ in the last two months. Dull aching constant right hypochondriac pain with no radiation and no aggravating factor but relieved with non-steroidal anti-inflammatory drugs. She had history of nausea but no vomiting. There were no stigmata of CLD, history of tuberculosis, or contact with a tubercular patient, skin rash, or arthritis. There was no remarkable personal history. General and systemic examination reveals the patient was mildly pale, icteric, and mild right hypochondriac tenderness. Investigation showed normal serum $\mathrm{Hb} 10.0 \mathrm{gm} / \mathrm{dl}$, ESR $120 \mathrm{~mm}$ in the first hour, white blood cell count $12700 / \mathrm{Cmm}$, differential count polymorph $75 \%$, lymphocyte $20 \%$, eosinophil $1 \%$, and monocyte $4 \%$. Liver function tests were S. Bilirubin: Total $5.4 \mathrm{mg} / \mathrm{dl}$, Direct $2.77 \mathrm{mg} / \mathrm{dl}$, S. ALT 96 U/L, S. ALP 259 U/L. S. Albumin 45g/l, PT and INR were normal. S. $\mathrm{LDH}$ and alpha-fetoprotein were also normal. Chest X-ray posterioranterior view was normal, MT test negative, Viral, autoimmune, and Wilson markers for hepatitis were negative.

USG of the whole abdomen revealed normal liver size with multiple hypoechoic focal lesions in the right lateral and posterior aspect of the right lobe, largest once measure $20 \times 14 \mathrm{~mm}$. The rest

Table 1: Laboratory and radiological investigations. of the liver parenchyma appears normal which is suggestive of space-occupying lesion. Computed Tomography (CT) scan of upper abdomen pre and post-contrast revealed liver is normal in size. Multiple peripherally enhancing mixed density lesions of variable sizes are noted in almost all segments of the right lobe of the liver. Peripherally enhancing collection seen in the porta hepatic region measuring about $5.0 \times 3.6 \mathrm{~cm}$ compressing the biliary channel. Possibilities are a) abscess b) Secondary metastasis. USG guided FNAC (Fine needle aspiration cytology) done from liver mass revealed ill-defined granulomas, granulation tissue, histiocytes, and lymphocytes. The background shows a small amount of caseous necrotic material and polymorphs. Malignant cells not seen.

Diagnosis: Granulomatous inflammation, cytologically consistent with tuberculosis. After getting the initial two months of Category-1 Anti TB therapy, the general condition of the patient improved with no jaundice and right hypochondriac pain. There were no space-occupying lesions in the USG scan of the liver. The continuation phase was started (Table 1).

\begin{tabular}{|c|c|c|}
\hline Investigation & Results & Normal range \\
\hline $\begin{array}{c}\text { Complete Blood Count } \\
\text { Haemoglobin }(\mathrm{g} / \mathrm{dL}) \\
\text { Erythrocyte sedimentation rate }\left(\mathrm{mm} \text { in } 1^{\text {st }} \mathrm{hr}\right) \\
\text { White blood cell count }(/ \mathrm{cu} \mathrm{mm}) \\
\text { Neutrophil leucocytes }(\%) \\
\text { Lymphocytes (\%) } \\
\text { Platelet count (/cu mm) }\end{array}$ & $\begin{array}{c}10.0 \\
120 \\
12,700 \\
75 \\
20\end{array}$ & $\begin{array}{c}13-17 \\
0-10 \\
4,500-11,000 \\
40-80 \\
20-40 \\
150,000-400,000\end{array}$ \\
\hline $\begin{array}{c}\text { Liver function tests } \\
\text { Total Bilirubin (mg/dl) } \\
\text { Direct Bilirubin (mg/dl) } \\
\text { Serum albumin (gm/L) } \\
\text { Prothrombin Time (sec) } \\
\text { International normalized ratio } \\
\text { Alanine aminotransferase (U/L) } \\
\text { Alkaline phosphatase (U/L) } \\
\text { Lactate dehydrogenase(U/L) } \\
\text { Alpha fetoprotein }\end{array}$ & $\begin{array}{c}5.4 \\
2.77 \\
45 \\
17 \\
1.4 \\
96 \\
259 \\
326 \\
1.54 \mathrm{ngm} / \mathrm{ml}\end{array}$ & $\begin{array}{c}0.3-1.0 \\
- \\
35-50 \\
12-16 \\
<1.4 \\
35-50 \\
128-356 \\
208-378 \\
<15 \mathrm{ngm} / \mathrm{ml}\end{array}$ \\
\hline $\begin{array}{c}\text { Viral markers } \\
\text { Hepatitis B surface antigen (HBsAg) } \\
\text { Antibodies to hepatitis C virus (Anti HCV) } \\
\text { Antibodies to hepatitis A virus (Anti HAV) Ig } \\
\text { MAntibodies to hepatitis E virus (Anti HEV) IgM }\end{array}$ & $\begin{array}{l}\text { Negative } \\
\text { Negative } \\
\text { Negative } \\
\text { Negative }\end{array}$ & \\
\hline $\begin{array}{c}\text { Autoimmune Markers } \\
\text { Anti nuclear antibody (ANA) } \\
\text { Anti LKM1 } \\
\text { IgG }\end{array}$ & $\begin{array}{l}\text { Negative } \\
\text { Negative } \\
12.5 \mathrm{~g} / \mathrm{l}\end{array}$ & $7-16 \mathrm{~g} / \mathrm{l}$ \\
\hline $\begin{array}{c}\text { Wilson disease markers } \\
\text { KF ring (Kayser-Fleischer ring) } \\
\text { S. Ceruloplasmin }\end{array}$ & $\begin{array}{c}\text { Absent } \\
39 \mathrm{mg} / \mathrm{dl}\end{array}$ & $20-60 \mathrm{mg} / \mathrm{dl}$ \\
\hline
\end{tabular}




\begin{tabular}{|c|c|}
\hline $\begin{array}{c}\text { X-ray chest } \\
\text { Mantouex Test }\end{array}$ & $\begin{array}{l}\text { Normal } \\
\text { Negative }\end{array}$ \\
\hline Ultrasonography of abdomen (figure 1) & $\begin{array}{l}\text { Normal size liver with multiple hypoechoic focal lesions in the right lateral and posterior aspect of } \\
\text { right lobe, largest once measure } 20 \times 14 \mathrm{~mm} \text {. Rest of the liver parenchyma appears normal which is } \\
\text { suggestive of space occupying lesion. (figure 1) }\end{array}$ \\
\hline $\begin{array}{c}\text { Computed Tomography (CT) of upper abdomen } \\
\text { (Figure 2) }\end{array}$ & $\begin{array}{l}\text { Liver is normal in size. Multiple peripherally enhancing mixed density lesions of variable sizes } \\
\text { are noted almost all segments of right lobe of liver. Peripherally enhancing collection seen in the } \\
\text { portahepatic region measuring about 5.0x3.6 cm compressing the biliary channel. Possibilities are } \\
\text { a) abscess b) Secondary metastasis. }\end{array}$ \\
\hline USG guided FNAC & $\begin{array}{l}\text { Clusters of epithelioid cells, many lymphocytes, some histiocytes and clusters of normal } \\
\text { hepatocytes. Background shows blood and small amount of caseous necrotic material. No malignant } \\
\text { cell seen. } \\
\text { Diagnosis: Granulomatous inflammation, suggestive of tuberculosis }\end{array}$ \\
\hline
\end{tabular}

\section{Discussion}

Tuberculosis is the most common infectious disease in Bangladesh like other developing countries. In local hepatic tuberculosis, tubercle size is $>2 \mathrm{~mm}$ in diameter and can be associated with a tuberculous focus elsewhere. The rarest form of local hepatic tuberculosis is isolated hepatic tuberculoma (nodular and macronodular hepatic tuberculosis) [8]. Most of the local hepatic tuberculosis has been reported by South Africa and the Philippines. Mode of transmission of mycobacterium TB to the hepatobiliary system is either by hematogenous route gastrointestinal foci, lymphatics, or to ruptured tuberculous lymph nodes near the portal tract. In localized hepatic TB tuberculous bacilli is spread through the lymphatics or due to rupture of tuberculous lymph nodes near the portal tract $[4,5]$. Whatever the mode of entry, granuloma formation is responded to by the liver. Both caseating and non-caseating granulomas can be seen. In focal tuberculosis, large tumor-like tuberculoma is formed by coalesces of various size granuloma. Caseating and liquefaction necrosis occur within tubercular granuloma and to form tubercular abscess [3] (Figures 1\& 2).

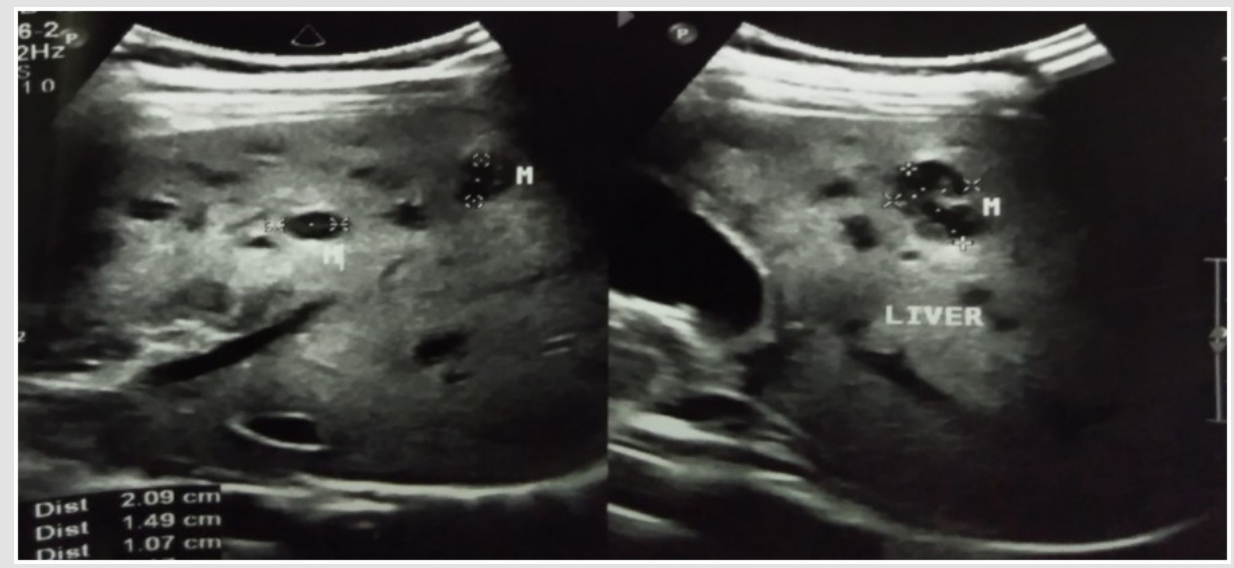

Figure 1: USG of liver.

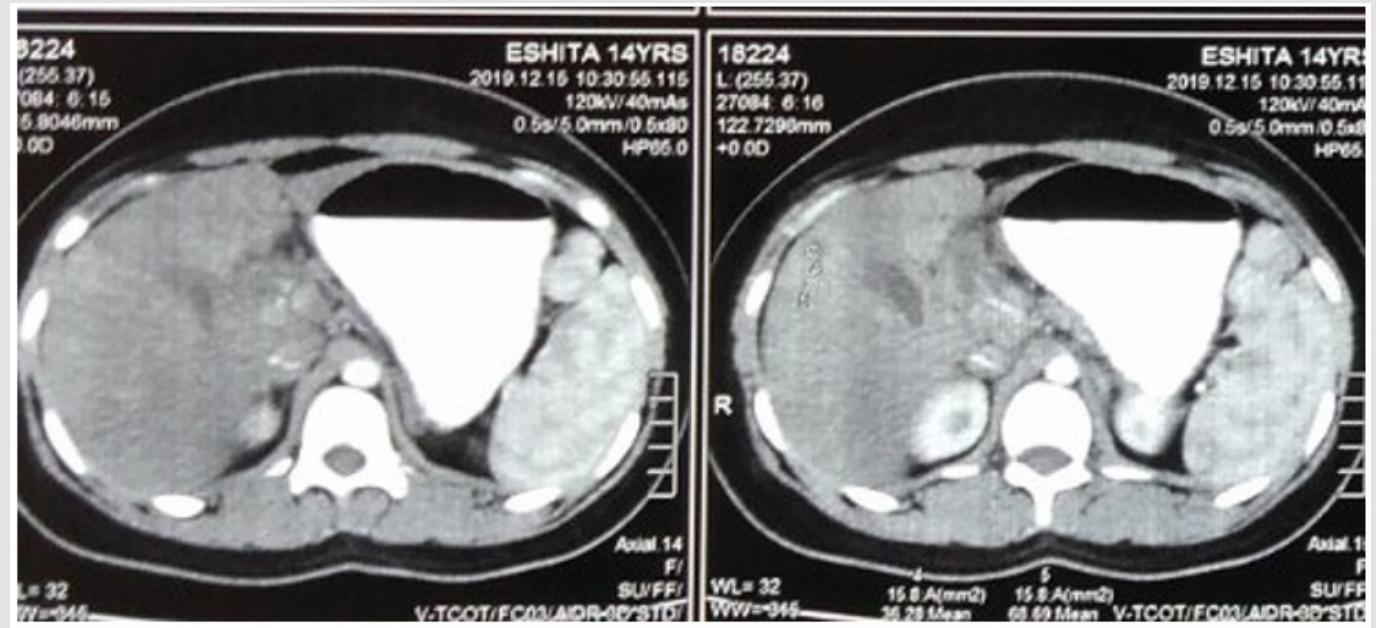

Figure 2: CT scan of liver. 
In world literature, 30-50 years are the common age group and usually presents with fever (50-90\%), abdominal pain (45$66 \%$ ), and hepatomegaly in localized hepatic TB [4,5]. Various clinical features, inconsistent of clinical and biochemical findings makes diagnosis difficult of patient of hepatic tuberculosis. Nonspecific and constitutional presenting complaints include anorexia, weight loss, night sweat, fever, malaise, and abdominal pain $[9,10]$. Generally, tuberculosis elsewhere is the clue for the diagnosis of hepatic involvement. Epigastric or right upper quadrant tenderness is a common manifestation [10]. Hepatomegaly is a common finding and can be associated with splenomegaly [11]; On the other hand, in the extensive miliary form, splenic involvement is common [12]. Jaundice can present due to direct destruction of the liver parenchyma by tuberculosis [10], with or without obstructive processes [12]. The most frequent clinical-laboratory findings in tuberculosis of the liver are hepatomegaly ( $\sim 90 \%)$, elevated serum alkaline phosphatase levels $(\sim 80 \%)$, fever $(\sim 70 \%)$, weight loss $(\sim 60 \%)$, and abdominal pain $(\sim 55 \%)$; all of them were present in our case. Moderate to a marked increase in the serum alkaline phosphatase level, along with normal or mildly increased serum bilirubin, is suggestive of hepatic tuberculosis; though these are not specific and may occur in other conditions, such as liver abscess, metastatic carcinoma, amyloidosis, echinococcosis, granulomatous diseases of other etiologies, and also inactive cirrhosis.

This type of biochemical abnormality was observed in our patient. Hyperglobulinemia and low serum albumin also suggestive of hepatic tuberculosis [13]. Normal to moderately raised aminotransferase and gamma glutamyl transpeptidase levels sometimes markedly raised are also seen. prothrombin time abnormality is a common finding in some series. Nonspecific laboratory findings, such as anemia and leukocytosis can be seen. Sometimes there is pancytopenia. Increased erythrocyte sedimentation rates are also common. In our case, most of these laboratory abnormalities were observed. Localized hepatic TB diagnosis is always difficult. Liver function abnormalities as elevated liver enzymes, hypoalbuminemia, hypogammaglobulinemia are non-specific and not helpful for definite diagnosis [4,5]. In our cases, the liver function test also did not help in a specific diagnosis. Sometimes, chest X-ray of hepatobiliary tubercular patients may show old tubercular lesions but only in $<10 \%$ cases, active pulmonary TB may be observed [4]. In our case, we could not find any radiographic or microbiological (sputum for acid-fast bacilli) evidence of pulmonary tuberculosis. A similar case of isolated hepatic TB was reported without any pulmonary lesion [7]. In localized hepatic TB, ultrasound examination of the liver shows nodular hypoechoic lesion or complex mass lesion mimicking primary or metastatic tumors. In our case, USG revealed hypoechoic lesion.

CT scan has some fallacies like ultrasound mimics a tumor. In our case, both CT scans and ultrasound misled us as a primary hepatic neoplasm or solitary metastatic nodule. Imaging-guided
FNAC can confirm the diagnosis, but in our case, only necrotic material but no acid-fast bacilli were not found in Ziehl Neelsen staining. For diagnosis of localized hepatic tuberculosis, Liver biopsy, either by image guidance or laparoscopic procedure and histopathology is a very effective tool. Caseous necrosis, multiple will form epithelioid granulomas, and presence of Langhans giant cells are the histopathological features of localized hepatic TB [4,5]. A caseous granulomatous lesion in liver biopsy is also observed in coccidioidomycosis, brucellosis, and Hodgkin's disease but clinical presentation is different $[5,14]$. In an endemic region, the absence of acid-fast bacilli, we should not distract from the diagnosis of tuberculosis [15]. Treatment of hepatic TB includes the standard four-drug regimen with isoniazid, rifampicin, ethambutol, and pyrazinamide as for any form of extrapulmonary TB. The duration of therapy is recommended generally for 1 year. Clinical improvement is frequently seen within $2-3$ months. Study shows that with 4 drug regime $67 \%$ of cases respond well with good clinical response. Despite the response, the overall mortality rate is $12 \%-42 \%$ and much higher in cases those present with jaundice (4). Adverse prognostic factors include acute presentation, younger age $(<20$ yr), and coagulopathy, etc for multiple large lesions and refractory lesions to medical treatment, surgery is an option [16,17]. In our case, the duration of therapy was 12 months; however, symptom relief was achieved within 2 months. Also, surgery is not required.

\section{Conclusion}

Isolated hepatic tuberculosis is a very rare form even in the endemic country for tuberculosis like Bangladesh. In an endemic country, when there is a liver mass in imaging study physicians should keep in mind that one of the differentials is hepatic tuberculosis. Clinically may resemble hepatic abscess but histopathology is the cornerstone of diagnosis.

\section{References}

1. Eisenach KD, Cave MD, Bates JH, Jack TC (1990) Polymerase chain reaction amplification of a repetitive DNA sequence specific for Mycobacterium tuberculosis. J Infect Dis 161: 977-981.

2. Synrang Batngen Warjri, Tony Ete, Taso Beyong, Bhupen Barman, Kyrshanlang G Lynrah, et al. (1994) Hepatic Tuberculosis: Uncommon Presentation of A Common Disease-A Case Report with Literature Review Ind J Tub 4: 131-134.

3. Azad KAK, Mallik MU, Hossain MZ, Shayekh A, Alam ASMM, et al. (2014) Isolated Hepatic Tuberculosis. J Dhaka Med Coll 23(1): 121-123.

4. Bandyopadhyay S, Maity PK (2013) Hepatobiliary tuberculosis. J Asso Physicians India 61(6): 404-407.

5. Alvarez S Z (2006) Hepatobiliary tuberculosis. Phil J Gastroenterol 2: 1-10.

6. Chong VH (2008) Hepatobiliary tuberculosis: a review of presentations and outcomes. South Med J 101(4): 356-361.

7. Khan ZR, Chowdhury MM, Saif Uddin M, Taher MA (2009) A Case Report: Isolated Liver Tuberculosis. BSMMU J 2(2): 88-89.

8. Oliva A, Duarte B, Jonasson O, Nadimpalli V (1990) The nodular form of local hepatic tuberculosis. J Clin Gastroenterol 12: 166.

9. Mert A, Ozaras R, Tabak F (2003) Localized hepatic tuberculosis. Eur J Intern Med 14: 511-512. 
10. Kok KYY, Yapp SKS (1999) Isolated hepatic tuberculosis: report of five cases and review of the literature. J Hepatobiliary Pancreat Surg 6: 195198.

11. I Tritou , P Prassopoulos, M Daskalogiannaki, N Charoulakis, O Papakonstantinou, et al. (2000) Miliary hepatic tuberculosis not associated with splenic or lung involvement. Acta Radiol 41: 478-481.

12. Hickey N, Mc Nulty JG, Osborne H, Finucane J (1999) Acute hepatobiliary tuberculosis: a report of two cases and a review of the literature. Eur Radiol 9: 886-889.

13. Chien RN, Lin PY, Liaw YF (1995) Hepatic tuberculosis: comparison of miliary and local form. Infection 23: 5-12.

ISSN: 2574-1241

DOI: $10.26717 /$ BJSTR.2020.29.004748

Md Benzamin. Biomed J Sci \& Tech Res

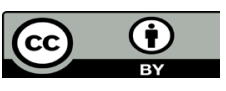

This work is licensed under Creative Commons Attribution 4.0 License

Submission Link: https://biomedres.us/submit-manuscript.php
14. Johnson LN, Iseri D, Knodell RG (1990) Caseating hepatic granulomas in Hodgkin's lymphoma'. Gastroenterology 99(6): 1837-1840.

15. Ibn Majdoub HK, Ousadden A, Ankouz A, Mazaz K, Taleb KA (2010) Isolated liver tuberculosis abscess in a patient without immunodeficiency: A case report. World J Hepatol 2(9): 354-357.

16. Poyrazoglu OK, Timurkaan M, Yalniz M, Ataseven H, Dogukan M, et al. (2008) Clinical review of 23 patients with tuberculous peritonitis: presenting features and diagnosis. J Dig Dis 9(3): 170-174.

17. Mert A, Ozaras R, Tabak F, Ozturk R, Bilir M (2003) Localized hepatic tuberculosis. Eur J Intern Med 14(8): 511- 512.

$\begin{array}{ll}\text { BIOMEDICAL } & \text { Assets of Publishing with us } \\ \text { RESEARCHES } & \text { - Global archiving of articles } \\ \text { - Immediate, unrestricted online access }\end{array}$

